\title{
Peranan Guru Dalam Administrasi Sarana Dan Prasarana Sekolah
}

\author{
Muhammad Akmal Al Farizi \\ Email:2010128310003@mhs.ulm.ac.id \\ Program Studi Pendidikan IPS Fakultas Keguruan Dan Ilmu Pendidikan \\ Universitas Lambung Mangkurat \\ Banjarmasin \\ 2021
}

\begin{abstract}
Abstrak
Salah satu aspek yang mendapat perhatian utama dari setiap administrator pendidikan adalah mengenai sarana dan prasarana pendidikan. Secara etimologis (bahasa) sarana berarti alat langsung untuk mencapai tujuan pendidikan. Sarana pendidikan umumnya mencakup semua peralatan dan perlengkapan yang secara langsung dipergunakan dan menunjang dalam proses pendidikan harus sesuai dengan proses pembelajarannya seperti gedung, ruang belajar atau kelas, alat-alat atau media pendidikan, meja, kursi, laboratorium dan sebagainya.
\end{abstract}

\section{Pendahuluan}

Fungsi dan peranan guru yang utama adalah mentransfer ilmu kepada siswa dalam proses belajar mengajar di ruang kelas, dan partisipasinya dalam pengembangan sekolah. Sebagai pelaksana tugas pendidikan, guru juga mempunyai andil dalam manajemen sarana dan prasarana pendidikan. Dalam hal ini, guru lebih banyak berhubungan dengan sarana pengajaran, yaitu alat pelajaran, alat peraga, dan media pengajaran lainnya.

Pengelolaan sarana dan prasaran merupakan salah satu bagian penting bagi sebuah instansi. Apalagi jika instansi tersebut juga mendapatkan bantuan dari pemerintah, maka administrasi sarana dan prasarana menjadi bagian vital, termasuk bagi instansi pendidikan yang dalam hal ini adalah sekolah. Untuk itulah pada artikel ini kami akan jelaskan pengertian administrasi sarana dan prasarana (sarpras) yang diambil dari pendapat ahli maupun sumber lain yang kredibel.

\section{Metode}

Artikel ilmiah hendaknya disusun dengan metode dan langkah-langkah yang sistematis untuk memudahkan dalam melakukan penelitian. Pada artikel ini, peneliti menggunakan metode studi literatur dengan cara mengumpulkan literatur (bahan-bahan materi) yang 
bersumber dari buku, jurnal, dan sumber lainnya terkait ilmu tentang Administrasi Pendidikan. Metode literatur yang berhubungan dengan topik yang diminati dapat membantu mempermudah dalam merumuskan masalah penelitian. Metode literatur ini bertujuan untuk membantu kita menemukan wawasan, kebenaran dan juga titik terang dari masalah yang akan diselasaikan. Sebagai petunjuk yang praktis sebaiknya menggunakan buku-buku dengan tanggal hak cipta terbaru. Semakin baru sebuah buku ditulis maka semakin besar wawasan dan kebenaran yang diperoleh.

\section{Pengertian Administrasi Sarana dan Prasarana Sekolah}

Menurut Kamus Besar Bahasa Indonesia (KBBI), sarana adalah segala sesuatu yang dapat dipakai sebagai alat dalam mencapai maksud atau tujuan. Menurut Ketentuan Umum Permendiknas (Peraturan Menteri Pendidikan Nasional) No. 24 tahun 2007. Sarana adalah perlengkapan pembelajaran yang dapat dipindah-pindah. sarana pendidikan menurut (Tim Penyusun Pedoman Media Pendidikan Departemen Pendidikan dan Kebudayaan) adalah semua fasilitas yang diperlukan dalam proses belajar mengajar, baik yang bergerak, maupun tidak bergerak, agar pencapaian tujuan pendidikan dapat berjalan dengan lancar, teratur, efektif dan efisien. Menurut Ibrahim Bafadal (2003: 2) sarana pendidikan adalah semua perangkatan peralatan, bahan dan perabot yang secara langsung digunakan dalam proses pendidikan di sekolah. (Ajar et al., 2006)

Sedangkan prasarana menurut Kamus Besar Bahasa Indonesia (KBBI) adalah segala sesuatu yang merupakan penunjang utama terselenggaranya suatu proses (usaha, pembangunan, proyek). Prasarana pendidikan merupakan semua komponen yang secara tidak langsung menunjang jalannya proses belajar mengajar di sekolah. Sebagai contoh: jalan menuju sekolah, halaman sekolah, gedung dan sebagainya (Tim Dosen Jurusan Administrasi Pendidikan FIP IKIP Malang. (Ajar et al., 2006)

Sarana pendidikan adalah peralatan dan perlengkapan yang secara langsung dipergunakan dan menunjang proses pendidikan khususnya proses belajar mengaja. Contohnya: gedung, ruang kelas, meja, kursi.

Administrasi Sarana dan Prasarana pendidikan merupakan seluruh proses yang direncanakan dan diusahakan secara sengaja dan bersungguh-sungguh serta pembinaan secara kontinu terhadap benda-benda pendidikan, agar senantiasa siap pakai (ready for use) dalam PBM sehingga PBM semakin efektif dan efisien guna membantu tercapainya tujuan pendidikan yang telah ditetapkan.

\section{Proses Administrasi Sarana dan Prasarana Sekolah}

Proses manajemen sarana prasarana pendidikan yang akan dibahas di sini berkaitan erat dengan:

a Perencanaan sarana prasarana pendidikan 
Perencanaan merupakan fungsi pertama yang harus dilakukan dalam proses manajemen. Proses perencanaan pengadaan perlengkapan sekolah merupakan kegiatan yang tidak mudah, membutuhkan analisis yang teliti dan memperhatikan kualitas sarana dan prasarana yang dibutuhkan. Ketersediaan dana juga memperhatikan skala prioritas dalam pengadaannya. Oleh karena itu, dalam proses perencanaan ini harus melibatkan semua personel sekolah agar dapat diketahui secara pasti tentang kebutuhan-kebutuhan yang diperlukan oleh sekolah, utamanya yang berkaitan langsung dengan proses pembelajaran di sekolah. Personel yang terlibat dalam proses perencanaan ini harus mengetahui secara pasti anggaran yang dikeluarkan oleh sekolah, harga sarana dan prasarana yang dibutuhkan. Selain itu, juga harus memberikan analisis tentang skala.

b Pengadaan sarana dan prasarana pendidikan

Pengadaan sarana prasarana pendidikan disekolah pada hakikatnya adalah kelanjutan dari program perencanaan yang telah disusun oleh sekolah sebelumnya. Dalam pengadaan ini harus dilakukan sesuai dengan rencana yang telah disusun sebelumnya dengan memperhatikan skala prioritas yang dibutuhkan oleh sekolah dalam menunjang keberhasilan pelaksanaan proses pembelajaran. Memilih sarana dan prasarana bukanlah berupa resep yang lengkap dengan petunjuk-petunjuknya lalu pendidik menerima resep begitu saja.

c Inventarisasi sarana dan prasarana pendidikan

Inventarisasi dapat diartikan sebagai pencatatan dan penyusunan daftar barang-barang milik Negara secara sistematis, tertib dan teratur berdasarkan ketentuan-ketentuan atau pedoman-pedoman yang berlaku. Hal ini sesuai dengan keputusan menteri keuangan RI Nomor Kep.225/MK/V/4/1971 bahwa barang milik negara berupa semua barang yang berasal atau dibeli dengan dana yang bersumber baik secara keseluruhan atau bagian sebagainya dari APBN ataupun dan lainya yang barang- barangnya dibawah penguasaan kantor departemen dan kebudayaan, baik yang berada didalam maupun luar negeri.

\section{d. Pendistribusian Sarana Prasarana Sekolah}

Pendistribusian perlengkapan merupakan kegiatan pemindahan barang dan tanggung jawab penyimpanan kepada unit-unit atau orang-orang yang membutuhkan barang itu. Dalam prosesnya ada 3 hal yang harus di perhatikan yaitu ketepatan barang yang di sampaikan, baik jumlah maupun jenisnya; ketepatan sasaran penyampaiannya, ketepatan kondisi barang yang di salurkan.

e. Pengawasan dan pemeliharaan sarana dan prasarana pendidikan

Pengawasan merupakan salah satu fungsi manajemen yang harus dilaksanakan oleh pimpinan organisasi. Berkaitan dengan sarana prasarana pendidikan di sekolah, perlu adanya kontrol baik dalam pemeliharaan atau pemberdayaan. Pengawasan terhadap sarana prasarana pendidikan disekolah merupakan usaha yang ditempuh oleh pimpinan dalam membantu 
personil sekolah untuk menjaga atau memelihara dan memanfaatkan sarana prasarana sekolah dengan sebaik mungkin demi keberhasilan proses pembelajaran disekolah.

Pemeliharaan terhadap sarana dan prasarana disekolah merupakan aktivitas yang harus dijalankan untuk menjaga agar perlengkapan yang dibutuhkan oleh personil sekolah dalam kondisi siap pakai. Kondisi siap pakai ini akan sangat membantu terhadap kelancaran proses pembelajaran yang dilaksanakan disekolah. Oleh karena itu, semua perlengkapan yang ada disekolah membutuhkan perawatan, pemeliharaan dan pengawasan agar dapat diberdayakan dengan sebaik mungkin.

\section{f. Penghapusan sarana dan prasarana sekolah}

Penghapusan sarana prasarana pendidikan adalah kegiatan meniadakan barang-barang milik lembaga (bisa juga milik negara) dari daftar inventaris dengan cara berdasarkan perundang-undangan yang berlaku. Kepala sekolah memiliki kewenangan untuk melakukan penghapusan terhadap perlengkapan sekolah. Namun perlengkapan yang akan dihapus harus memenuhi persyaratan-persyaratan penghapusan.

\section{Peranan Guru Dalam Administrasi Sarana dan Prasarana Sekolah}

Peranan guru dalam administrasi sarana dan prasarana pendidikan adalah dimulai dengan perencanaan, pemanfaatan, pemeliharaan, serta pengawasan penggunaan prasarana dan sarana. (Eliyanto, 2013)

Kebijakan pemerintah tentang pengelolaan sarana dan prasarana sekolah tertuang di dalam UU No. 20 tahun 2003 tentang Sisdiknas pasal 45 ayat (1) yaitu "setiap satuan pendidikan formal dan nonformal menyediakan sarana dan prasarana yang memenuhi keperluan pendidikan sesuai dengan pertumbuhan dan perkembangan potensi fisik, kecerdasan intelektual, sosial, emosional dan kejiwaan peserta didik." (Mohammad Syaifuddin, 2007 : 2.36).

Adapun peran guru dalam administrasi sarana prasarana sekolah:

1. Terlibat dalam perencanaan pengadaan alat bantu pengajaran.

2. Terlibat dalam pemanfaatan dan pemeliharaan alat bantu pengajaran yang digunakan guru.

3. Pengawasan dalam penggunaan alat praktek oleh siswa. (Yuliana, Y \& Afriansyah, 2019)

\section{Kesimpulan}

Administrasi sarana dan prasarana pendidikan itu adalah semua komponen yang secara langsung maupun tidak langsung menunjang jalannya proses pendidikan untuk mencapai tujuan dalam pendidikan itu sendiri. Administrasi Sarana dan Prasarana sekolah merupakan seluruh proses yang direncanakan dan diusahakan secara sengaja dan bersungguh-sungguh serta pembinaan secara kontinu terhadap benda-benda pendidikan, agar senantiasa siap pakai (ready for use) dalam PBM sehingga PBM semakin efektif dan efisien guna membantu 
tercapainya tujuan pendidikan yang telah ditetapkan Pada Administrasi sarana prasarana meliputi 5hal yakni Penentuan kebutuhan, Proses pengadaan, Pemakaian ,Pencatatan pengurusan dan Pertanggungjawaban. kegiatan administrasi sarana dan prasarana pendidikan meliputi perencanaan pengadaan barang, pengadaan barang, penyimpanan, inventarisasi, penyaluran, pemeliharaan, rehabilitasi, penghapusan dan pengendalian. Adapun peran guru dalam administrasi sarana prasarana sekolah yaitu Terlibat dalam perencanaan pengadaan alat bantu pengajaran, Terlibat dalam pemanfaatan dan pemeliharaan alat bantu pengajaran yang digunakan guru dan Pengawasan dalam penggunaan alat praktek oleh siswa.

\section{Daftar Pustaka}

Zafar, M. A., \& Afriansyah, H. (2019). Administrasi Sarana Prasarana.

Afriansyah, H. (2019). Administrasi sarana dan prasarana.

Fitri, D. Z. (2020). Pengertian Administrasi Sarana Dan Prasarana, Proses Administrasi Sarana Dan Prasarana Dan Peran Guru Dalam Administrasi Sarana Dan Prasarana.

Ajar, B., Diklat, D., Sekolah, M., Penataran, P., Guru, P., Dan, I. P. S., \& Malang, P. M. P. (2006). Administrasi Pendidikan.

Eliyanto, U. B. W. (2013). Jurnal Akuntabilitas Manajemen Pendidikan. Pengaruh Jenjang Pendidikan, Pelatihan, Dan Pengalaman Mengajar Terhadap Profesionalisme Guru SMA Muhammadiyah Di Kabupaten Kebumen, 1, Nomor 1, 34-47. 